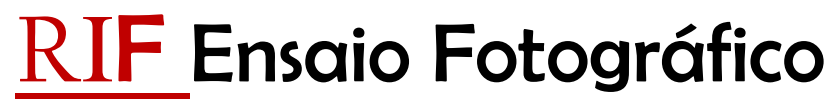

\author{
DOI - 10.5212/RIF.v.18.i41.0014
}

\section{México Colorido}

Fotos e texto: Marcelo Sabbatini ${ }^{1}$

O México, como país, consiste de um mosaico heterogêneo de culturas, miscigenando os traços culturais e idiomáticos dos povos indígenas pré-colombianos, com uma geografia diversificada com os diferentes elementos da colonização europeia. Um país de tradição históricas milenares que nos impactam até os dias de hoje, inclusive atravessando suas fronteiras. E dentre de suas características culturais, algo que impacta qualquer viajante que chegue a suas terras é a presença da cor. Não somente do colorido, mas de um colorido extramente brilhante, saturado. Ele está nas paredes das casas, nas roupas, nas ruas e inclusive nos alimentos e na culinária.

Mas como explicar este uso das cores pelo povo mexicano? Recorrendo às teorias da percepção, a cor possui uma capacidade de significação dependente de seu contexto cultural, participando portanto do processo de interpretação de uma mensagem, no que se designa "cor informação". Sua natureza de código cultural é influenciada por sua vez pelo código da linguagem e por aspectos biofísicos. Assim:

\begin{abstract}
As cores são usadas com determinados valores simbólicos, que ao serem apreendidas, antecipam a informação. Isso acontece quando o leitor já está familiarizado com o seu uso em um processo de reconhecimento do contexto no qual aquela cor foi inserida. Todo o processo termina e recomeça no receptor, pois é ele quem retroalimenta o sistema informativo contribuindo com suas experiências e criatividade para que o signo se sustente ou sofra alterações. As cores tomam forma levando-se em conta seus significados coletivos em uma determinada cultura, organizações do código linguístico e sensações biofísicas que atuam independentes da intencionalidade do homem (TEIXEIRA, 2006, p. 1098).
\end{abstract}

\footnotetext{
${ }^{1}$ Doutor em Teoria e História da Educação Universidad de Salamanca (Espanha) em 2004. Pós-doutorado realizado no Programa de Extensão Rural e Desenvolvimento Local - POSMEX da Universidade Federal Rural de Pernambuco, 2006. Professor do Departamento de Fundamentos Sócio-Filosóficos da Educação do Centro de Educação da Universidade Federal de Pernambuco (UFPE) e do Programa de Pós-Graduação em Educação Matemática e Tecnológica da mesma instituição. Sócio-fundador da Rede de Estudos e Pesquisa em Folkcomunicação (2006-2013). Correio eletrônico: marcelo.sabbatini@ufpe.br.
} 


\section{RIF, Ponta Grossa/ PR Volume 18, Número 41, p.249-263, Julho/Dezembro 2020}

Particularmente, numa cultura reconhecida mundialmente por sua originalidade, o atual código cultural de uso das cores pode ser resultado do crisol das diversas culturas que conformaram este país. Cabe destacar que a intensa miscigenação das culturas que ocorreu ao longo do século XX e que criou novas correntes na arte, artesanato e patrimônio cultura imaterial foi consequência de um projeto de desenvolvimento nacional promovido pelo Estado pós-revolucionário, que defendeu e proporcionou as condições aos mexicanos de fazerem sua cultura florescer. Assim,

a mexicanidade, como vontade coletiva nacional, faz parte da combinatória do nacionalismo como do cosmopolitismo de diversas fontes políticas. Esta mexicanidade se baseia, tanto na força de compartilhar uma história que nos fere, como no desejo de comunicar e intercambiar diversidades, o que explica a grande criatividade cultural dos mexicanos (ARIZPE, 2011, p. 81).

Como relatam Bortoli e Maroto (2008), a pesquisa internacional sobre os significados das cores mostrou que o vermelho, o laranja, o amarelo e o dourado se encontram junto ao pólo identificado com os conceitos de "ativo, excitante, feroz, quente, vibrante, violento". Estas são cores bastante presentes no colorido mexicano e que culturalmente representam o Sol (amarelo) e a religião, vibração, intensidade e a própria morte (vermelho). Em nossa própria percepção, suas predominâncias podem ser associadas com "a festa, a feira, a comemoração, o simulacro, o festejo, o relaxar, que através dos séculos vêm se despejando do grande calendário de ritos e festividades da Mesoamérica" (ARIZPE, 2011, p. 73).

Por sua vez, Érico Veríssimo relata em seu misto de relato de viagem e de ensaio sobre a história, a cultura e o caráter mexicano que a terra, o povo e a comida do México estão em sintonia no que diz respeito às cores; sentidos e emoções provocados por eles são similares. Dessa forma:

cor, essa nota viva - aparece também na comida. São os chiles - encarnados, amarelos, mulatos, verdes - o vermelhão dos tomates, as flores de calabaza, as ervas aromáticas, coisas que alegram, pelo menos na superfície, a parda secura da tortilla e dos outros partos de aspecto árido ou crepuscular (VERISSIMO, 1978, p.147 apud LUCENA, 2016, p. 4).

Nesse ponto, Veríssimo utiliza-se de Octavio Paz e seu "Labirinto da Solidão" como referência para respaldar suas impressões, destacando que as cores para o povo mexicano atuam como "máscaras", instrumentos de defesa que ocultam sua natureza (LUCENA, 2016). 


\section{RIF, Ponta Grossa/ PR Volume 18, Número 41, p.249-263, Julho/Dezembro 2020}

Ainda sobre o aspecto cultural, Hoopley (2010) comenta que na cultura norteamericana o colorido é uma característica dos relativamente marginalizado, como artistas, boêmios e hippies. Na mentalidade anglo-saxã, a cor seria um "sinal de uma mente perigosa, de um quebrador de regras impulsivo, de alguém que não tem medo de se destacar". Ainda mais, o mundo "adulto" e "profissional" seria caracterizado por cores sóbrias: as "não-cores" branco, preto e cinza, além dos beges e tons pastéis que se adequam às regras e normas de conduta da sociedade. O México, por outro lado, traria em seu colorido a expressão de uma atitude diferente da sociedade em relação à vida - uma atitude de maior liberdade e de tomada de riscos.

Particularmente na capital, uma cor chama a atenção: um rosa mais escuro, magenta², presente entre outros lugares nos diversos meios de transporte urbano, e notadamente os táxis. A expressão "rosa mexicano" foi cunhada nos anos 1950 e incorporada pelo Consejo de Promoción Turística de México e pela administração da metrópole, identificada pelo acrônimo CDMX (Cidade do México) como uma forma de identificação de seu povo e de sua cultura. Num estudo cognitivo de identificação de cor tonalidade efetivamente foi identificada como representativa dos povos mexicanos tradicionais em comparação ao rosa mais claro, ou fúcsia. Esta apropriação da cor une então o anseio de uma elite cultural buscando uma estética de identificação para as artes e para a moda, em consonância com a cultural rural e mestiça (MUKHOPADHYAY et al., 2017).

Foi diante deste rico contexto que como viajante, com o olhar etnográfico de alguém que está fora da cultura, também fui impactado pelas cores do México. O ensaio agora apresentado é resultado do registro fotográfico realizado em viagem pelo país, por ocasião do XII Congresso da Associação Latino-Americana de Investigadores da Comunicação (ALAIC), realizado em $2016^{3}$.

Nele encontramos vários elementos da cultura, tradicional, moderna, miscigenada que se expressam vividamente através de cores intensas e vibrantes. Do colorido das casas, passando pelo artesanato têxtil de raiz e chegado aquele ressignificado para o consumo

\footnotetext{
${ }^{2} \mathrm{Na}$ Escala de Cores Pantone ("Pantone Matching System" ou PMS), representada pelo código \#E50087.

3 Uma versão mais completa do ensaio pode ser encontrada em http://marcelo.sabbatini.com/mexicocolorido/
} 


\section{RIF, Ponta Grossa/ PR Volume 18, Número 41, p.249-263, Julho/Dezembro 2020}

turístico. Passando pelos alimentos, processados ou naturais, além da própria fauna. Pelo contraste das construções históricas com as arrojadas arquiteturas de um México inserido no âmbito do capitalismo neoliberal. Pelos barcos do canal de Xochimilco e, perto dali, pelas tintas de Frida Kahlo. Pela fiesta, outra característica essencial da cultura mexicana e por sua presença no monumento que celebra a Revolução que deu origem a um dos períodos mais férteis da produção cultural deste país.

\section{Foto 01: Bairro periférico da Cidade do México, caracterizado pelas fachadas coloridas} das casas.

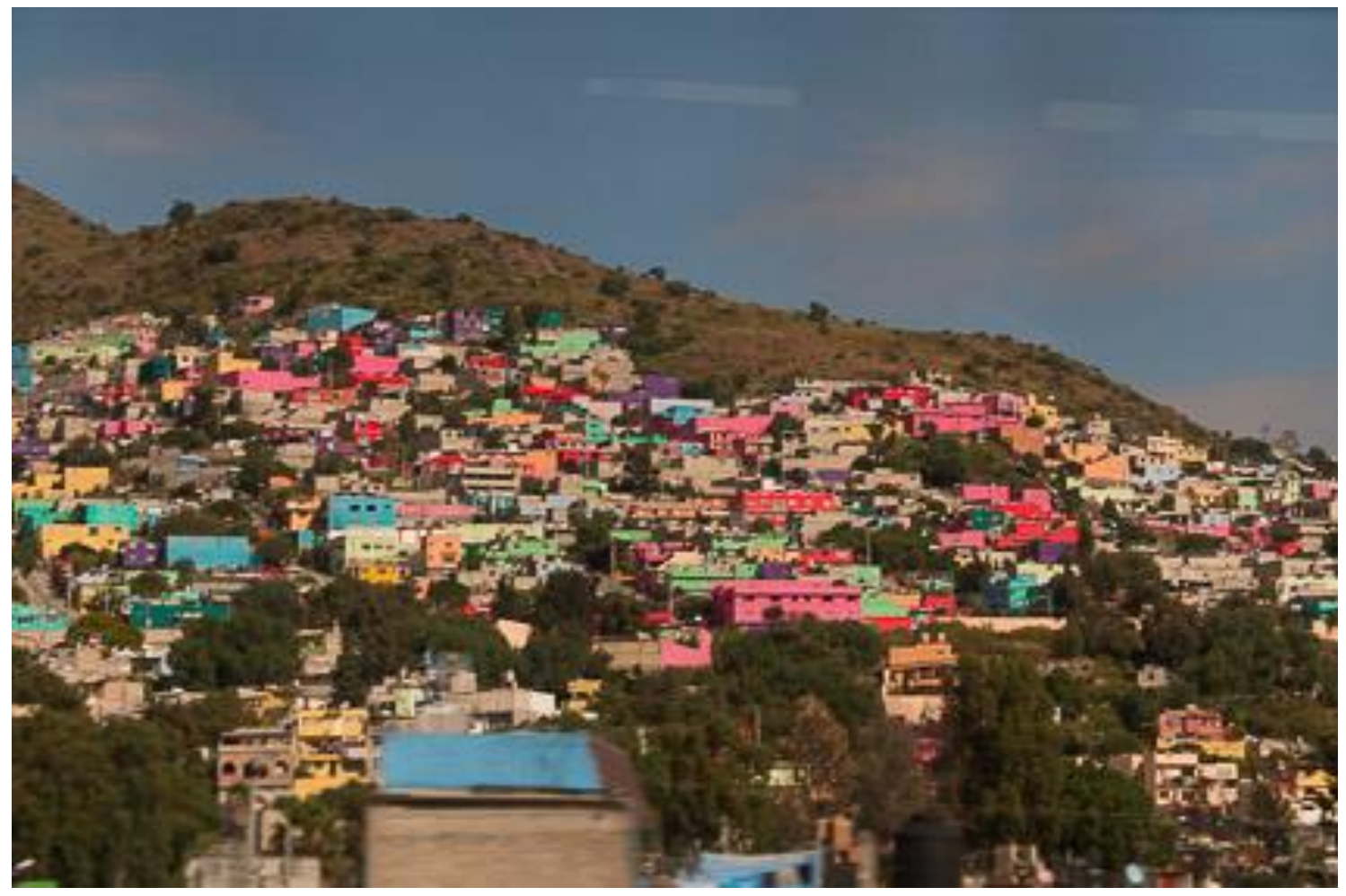


RIF, Ponta Grossa/ PR Volume 18, Número 41, p.249-263, Julho/Dezembro 2020

Foto 02: Artesanato têxtil e o cacto chamado agave, de onde são retiradas fibras, além de ser produzida a tequila e o mezcal

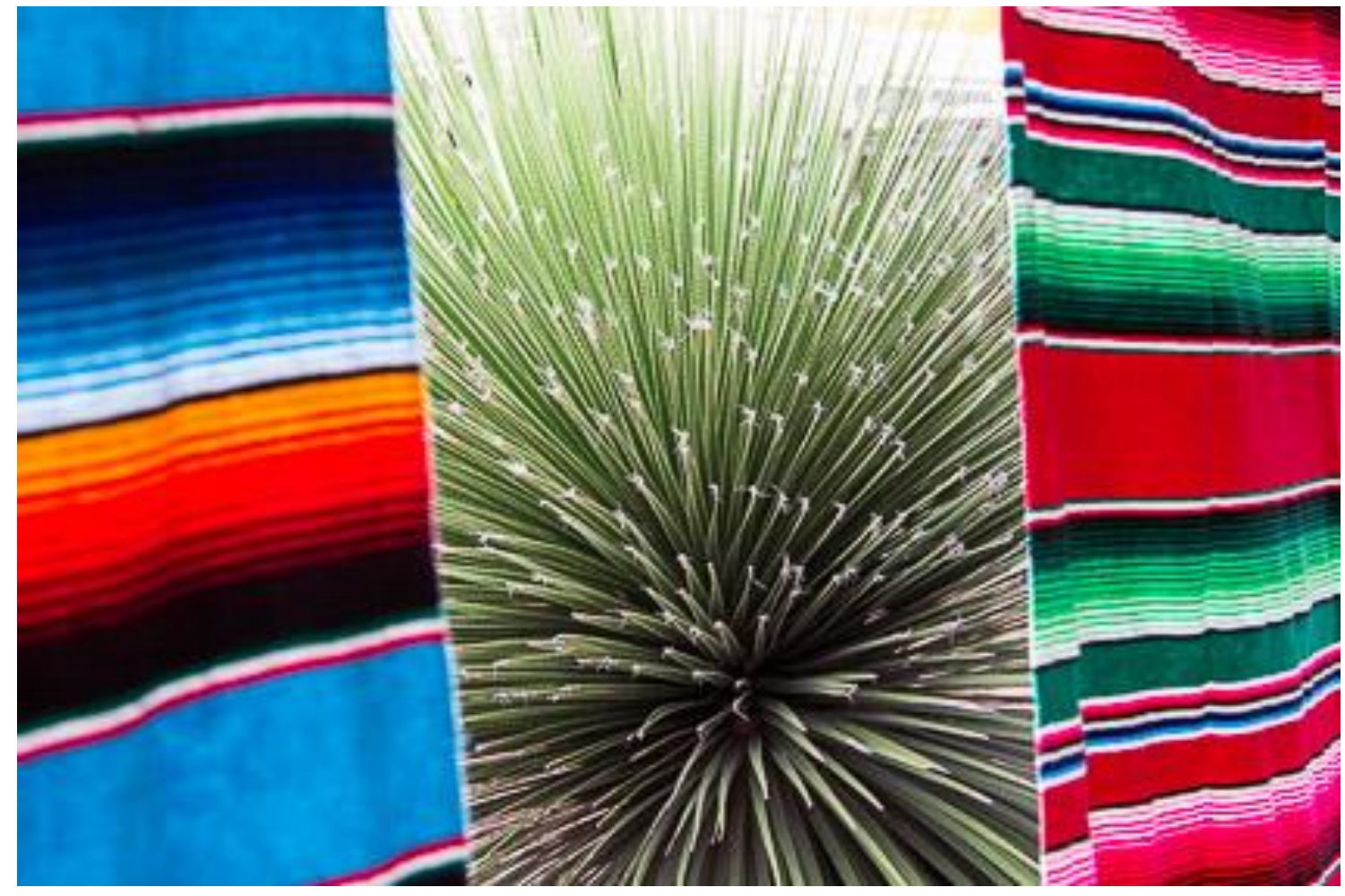


RIF, Ponta Grossa/ PR Volume 18, Número 41, p.249-263, Julho/Dezembro 2020

Foto 03: As caveiras, simbolizando a vida e a proteção contra os maus espíritos, em versão souvenir.

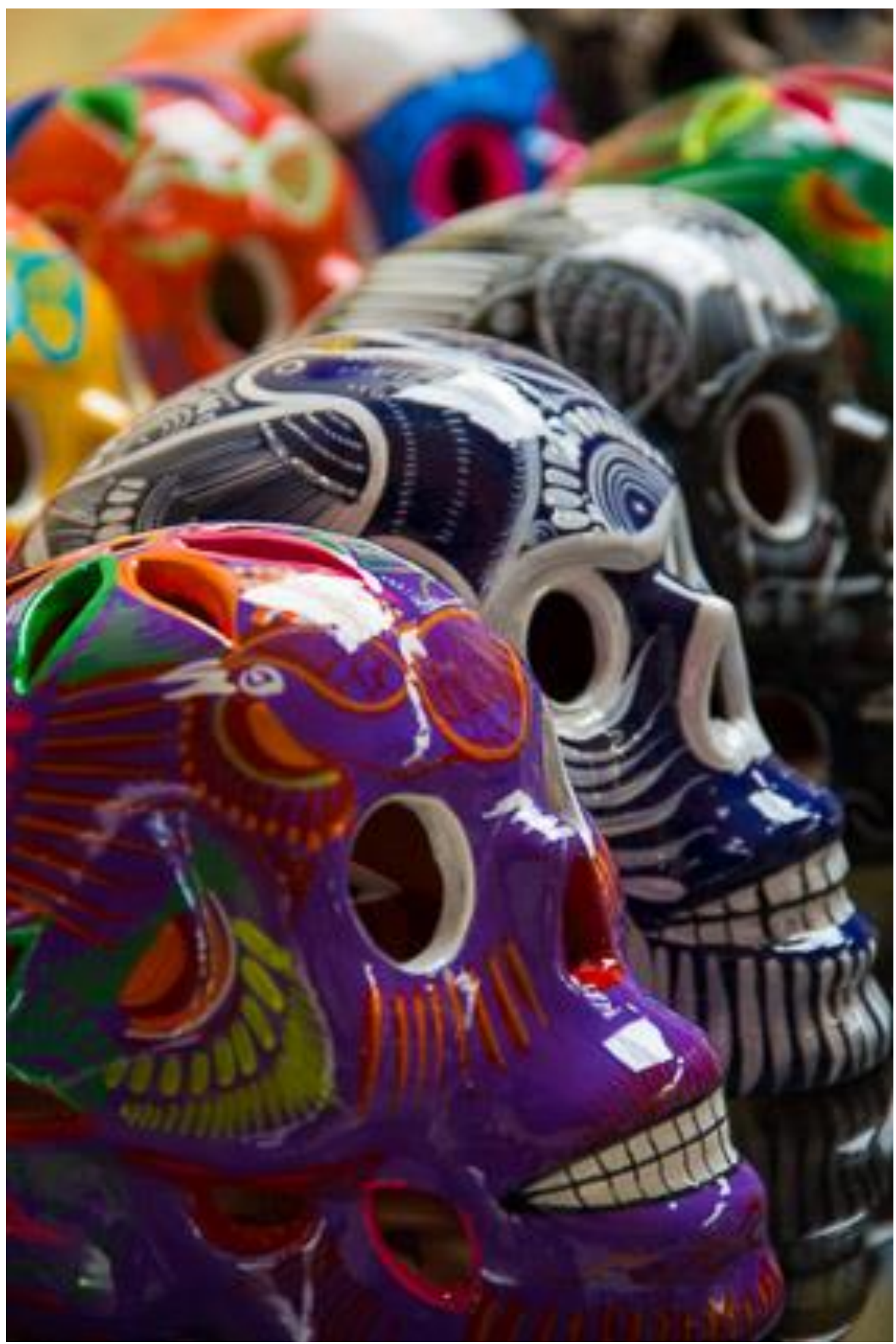

254 | México Colorido 
RIF, Ponta Grossa/ PR Volume 18, Número 41, p.249-263, Julho/Dezembro 2020

Foto 04: Anjo e demônio, decoração de moderno hotel-boutique; cores vibrantes sempre associadas à religião

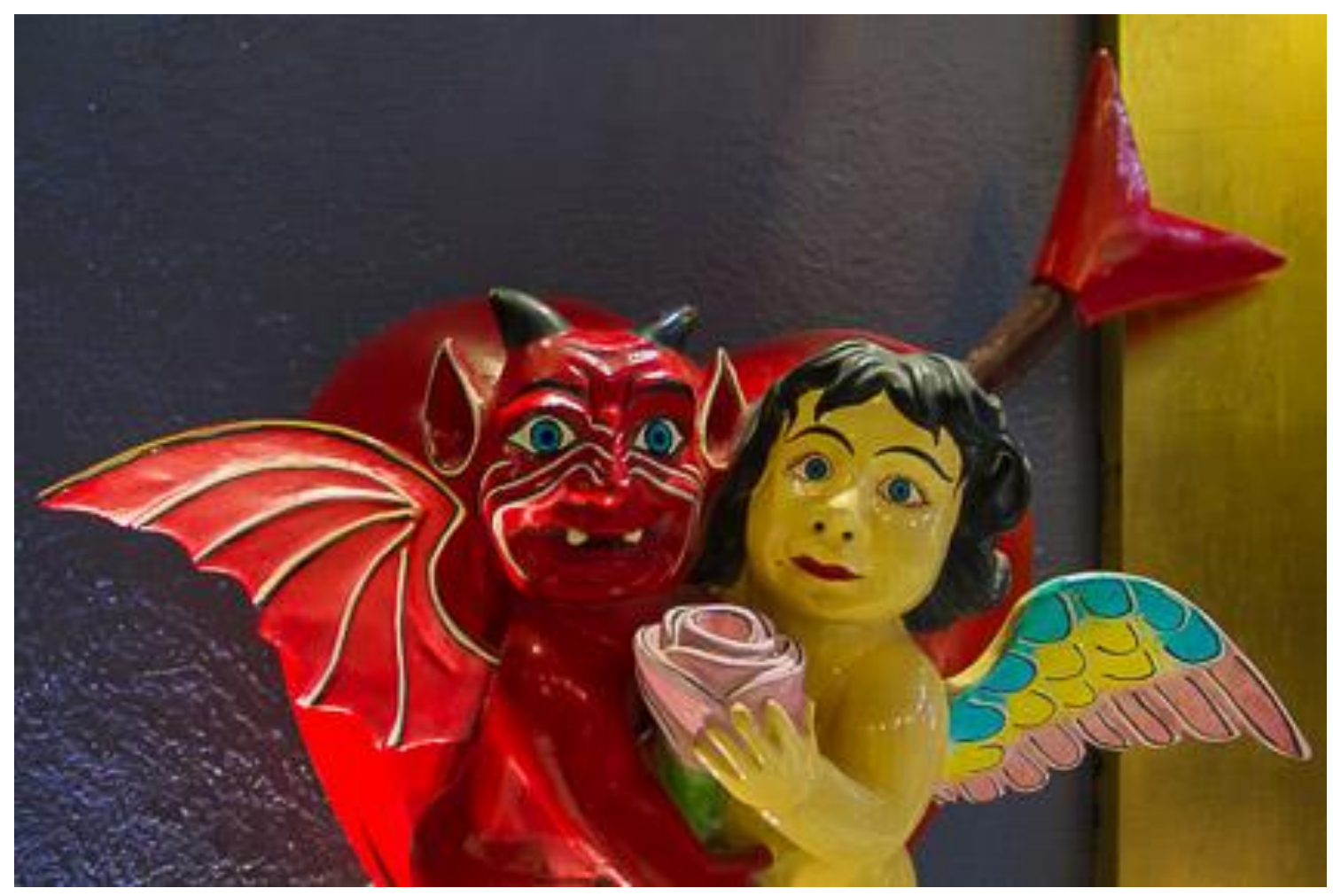


RIF, Ponta Grossa/ PR Volume 18, Número 41, p.249-263, Julho/Dezembro 2020

Foto 05: Os táxis na Cidade do México, no característico "rosa mexicano"

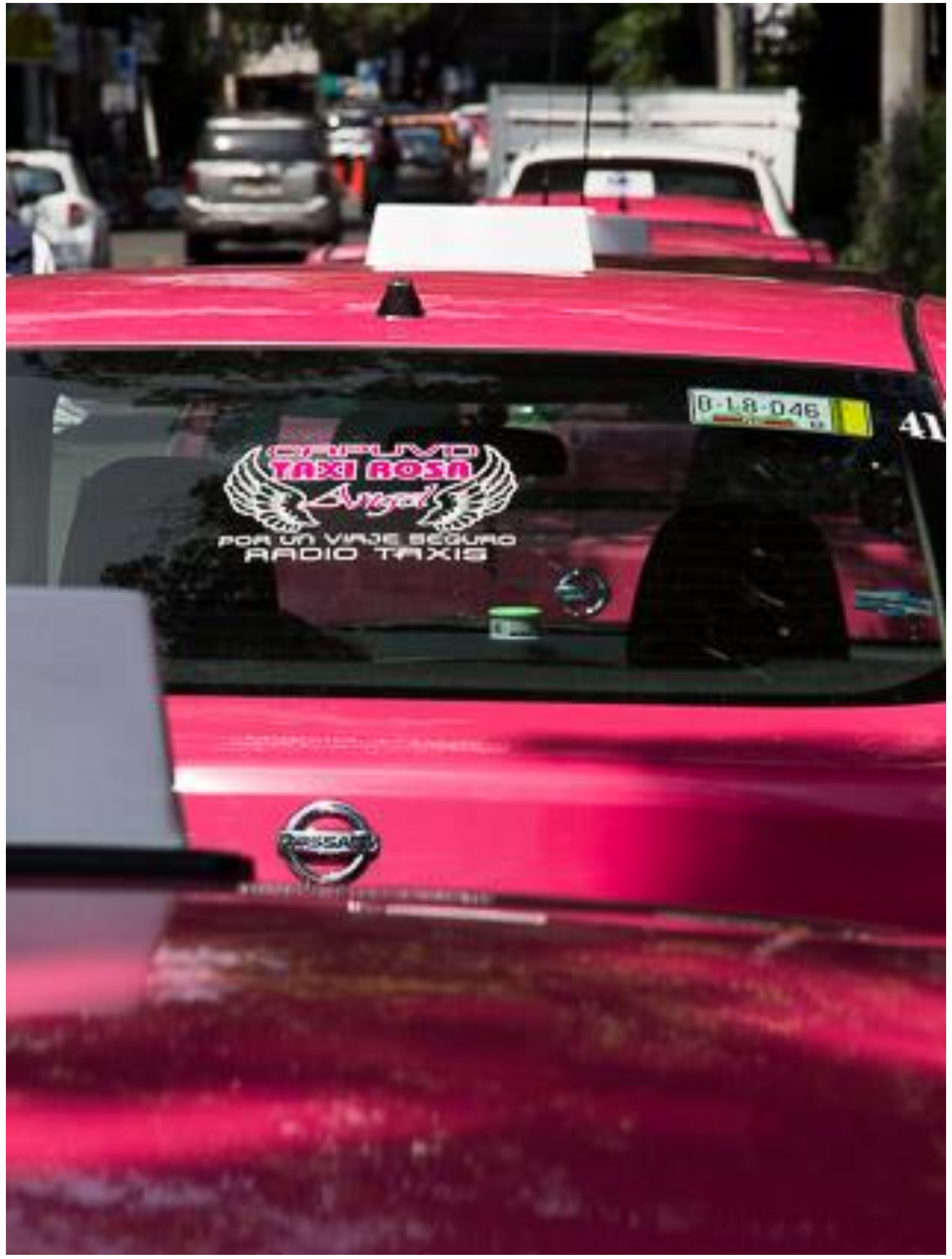


RIF, Ponta Grossa/ PR Volume 18, Número 41, p.249-263, Julho/Dezembro 2020

Foto 06: Casquinhas de sorvete, se podem ser coloridas, por que não?

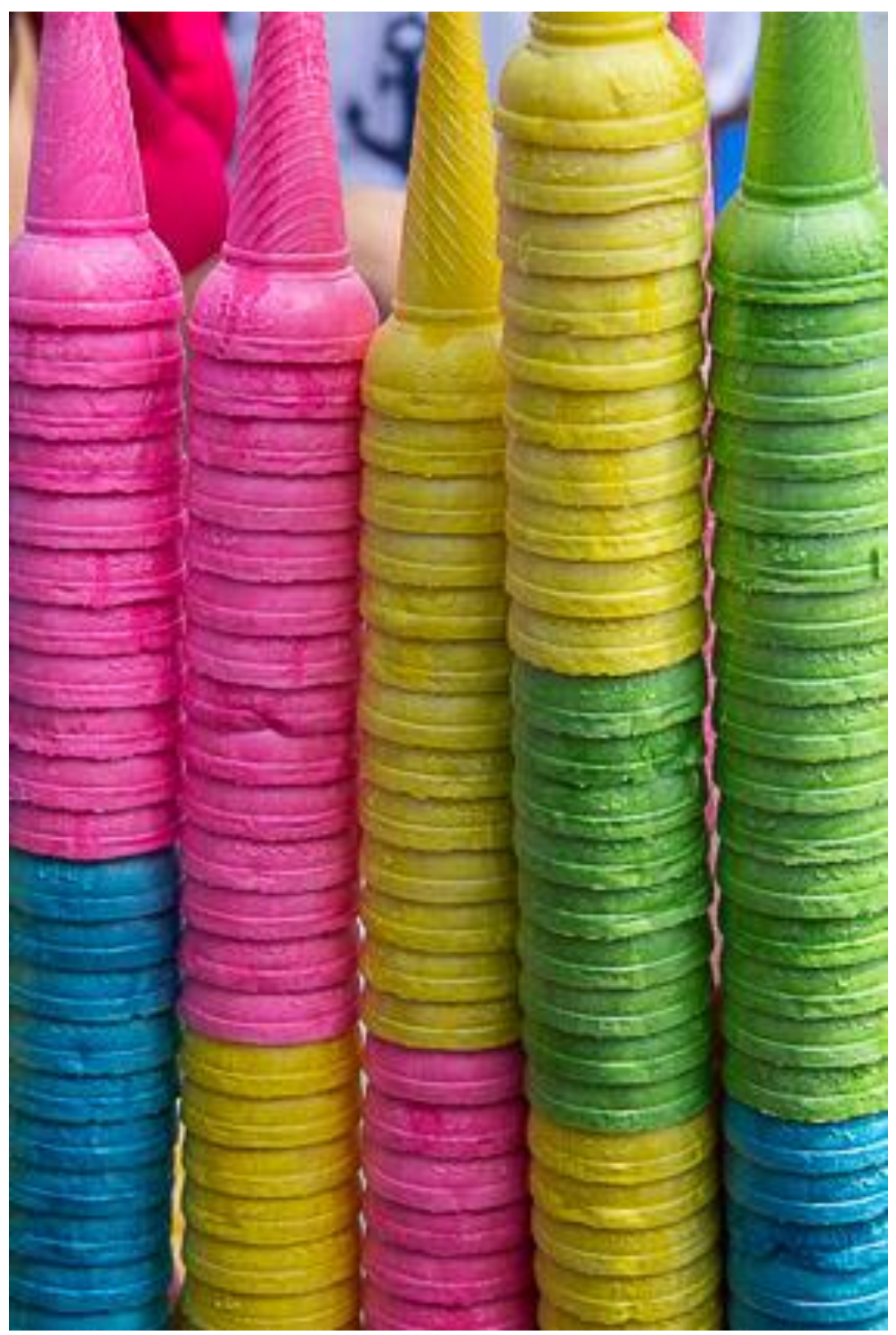


RIF, Ponta Grossa/ PR Volume 18, Número 41, p.249-263, Julho/Dezembro 2020

Foto 07: Doces no comércio de rua, callejero, uma tradição gastronômica de raiz popular, um espectro barroco de texturas e sabores.

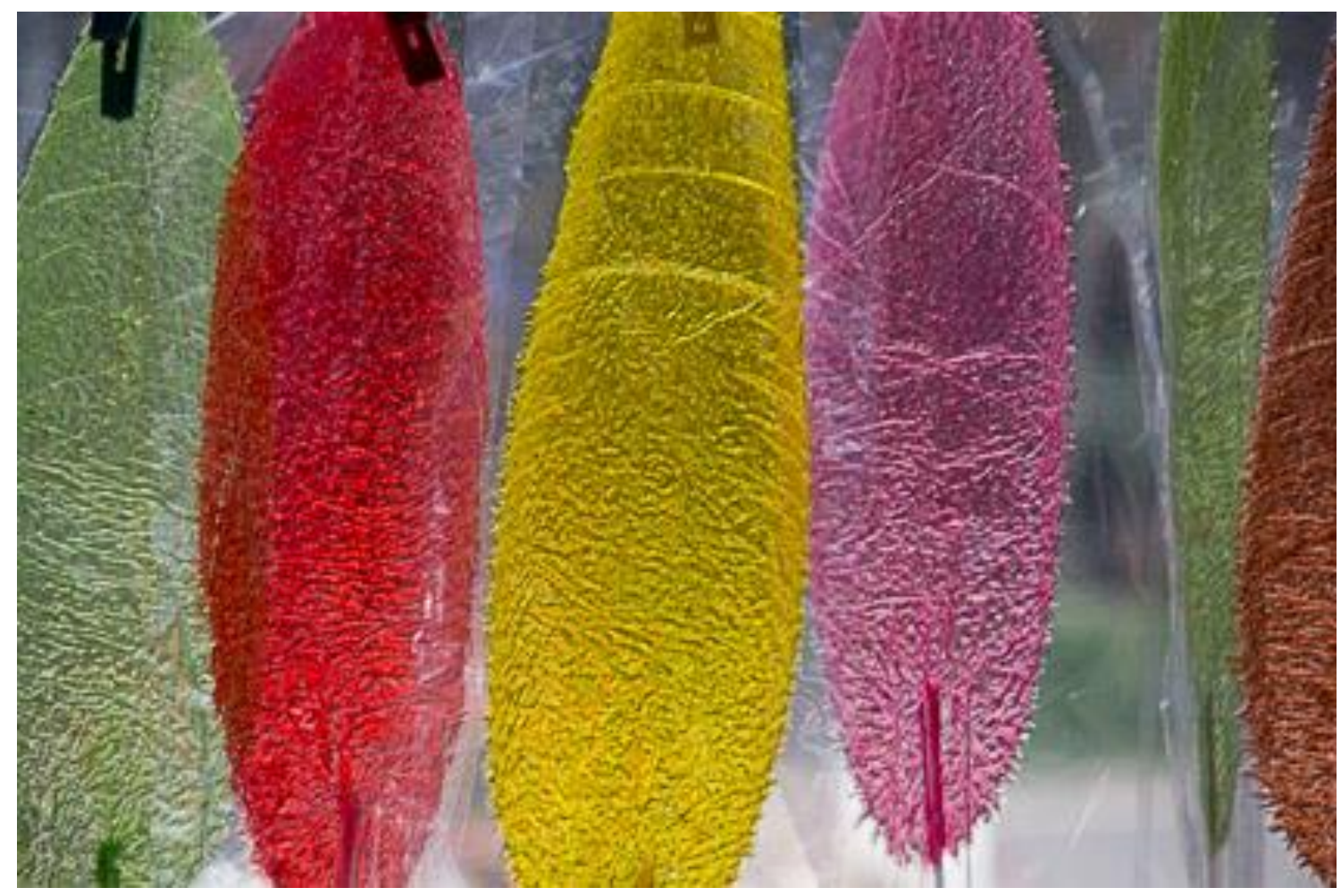

Foto 08: Manga, laranja, melancia, mamão, natural e intenso.

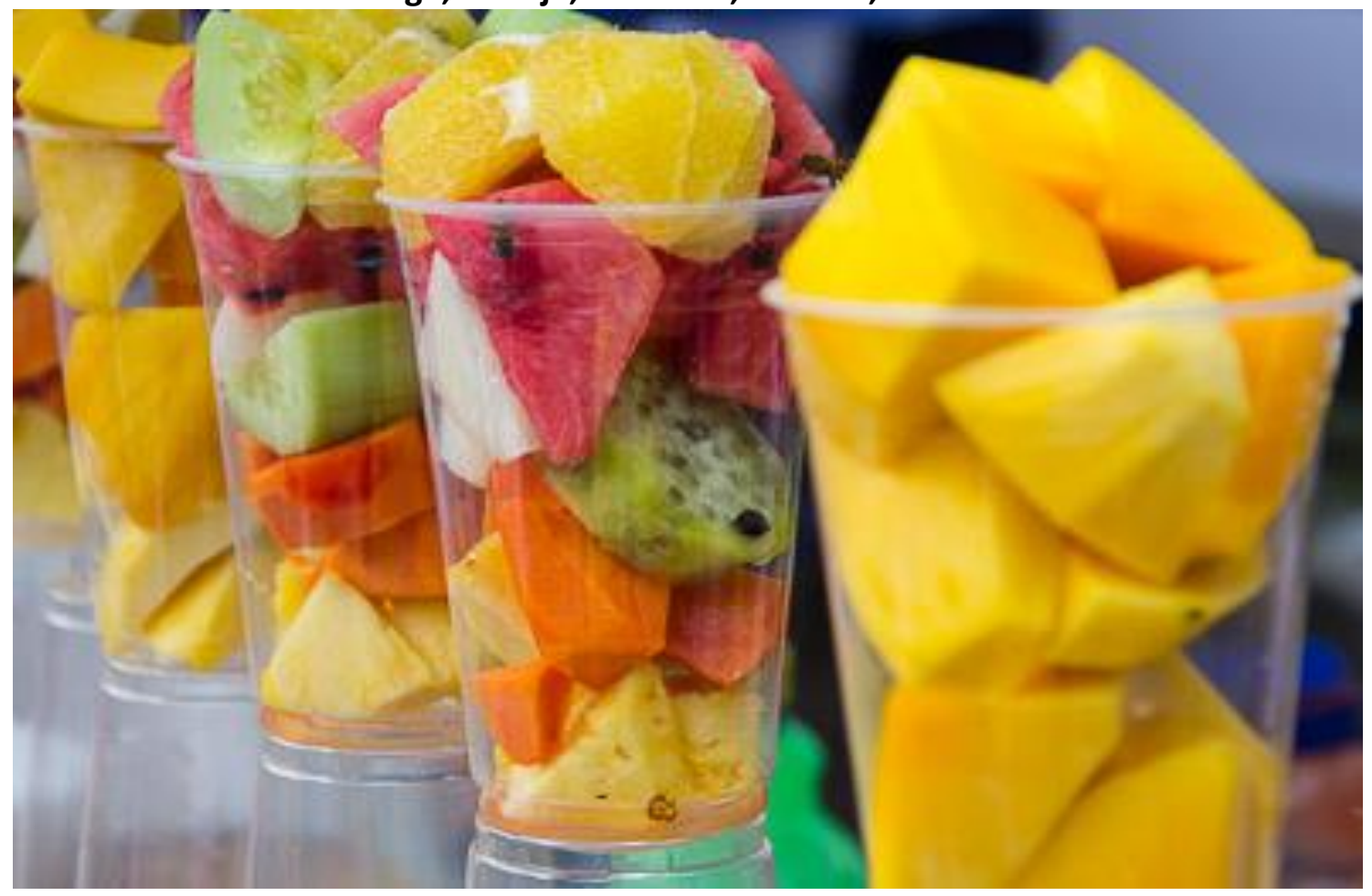


RIF, Ponta Grossa/ PR Volume 18, Número 41, p.249-263, Julho/Dezembro 2020

Foto 09: Uma iguana, nada sóbria, em seu disfarce natural

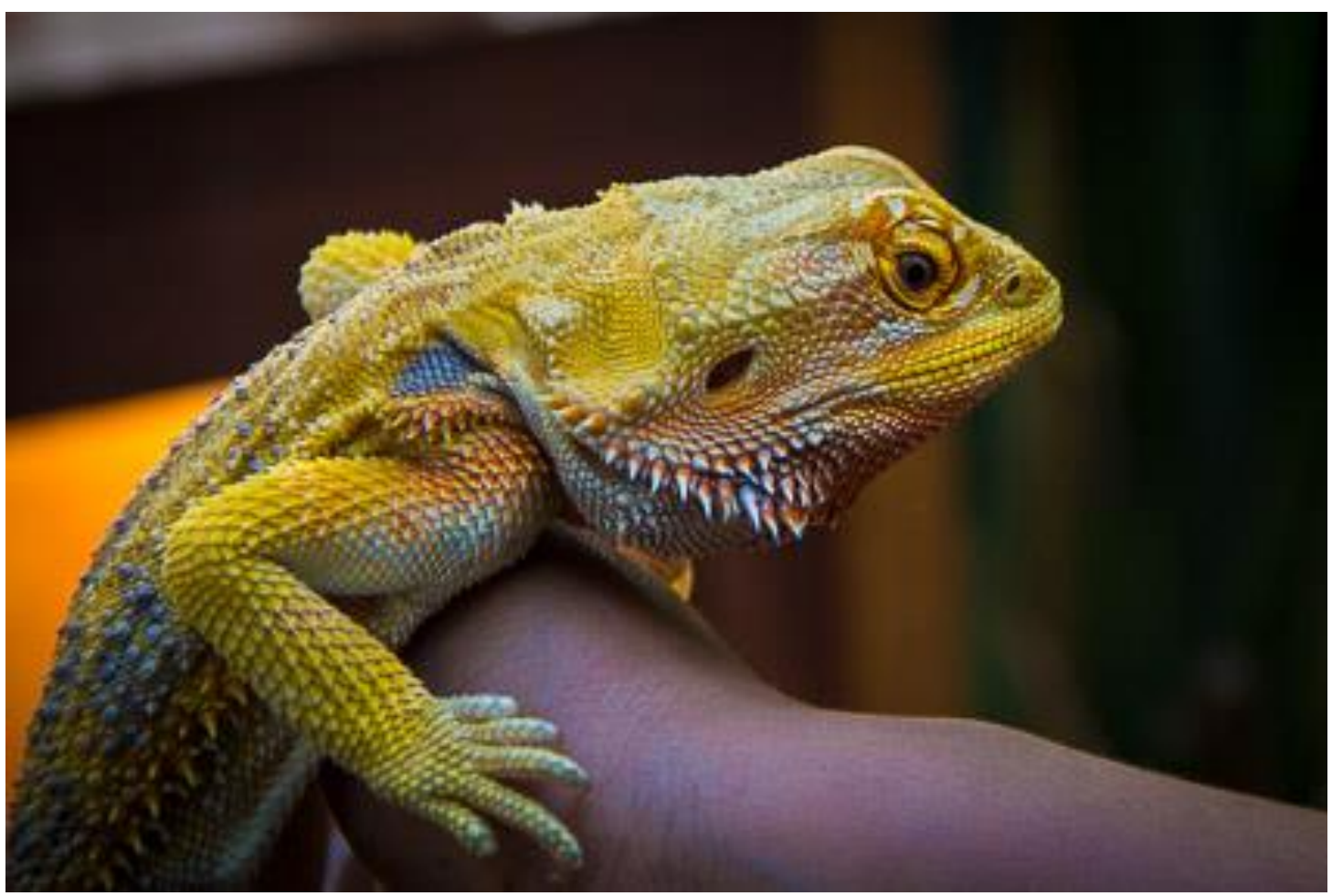

Foto 10: Azulejos, Centro Histórico da Cidade do México

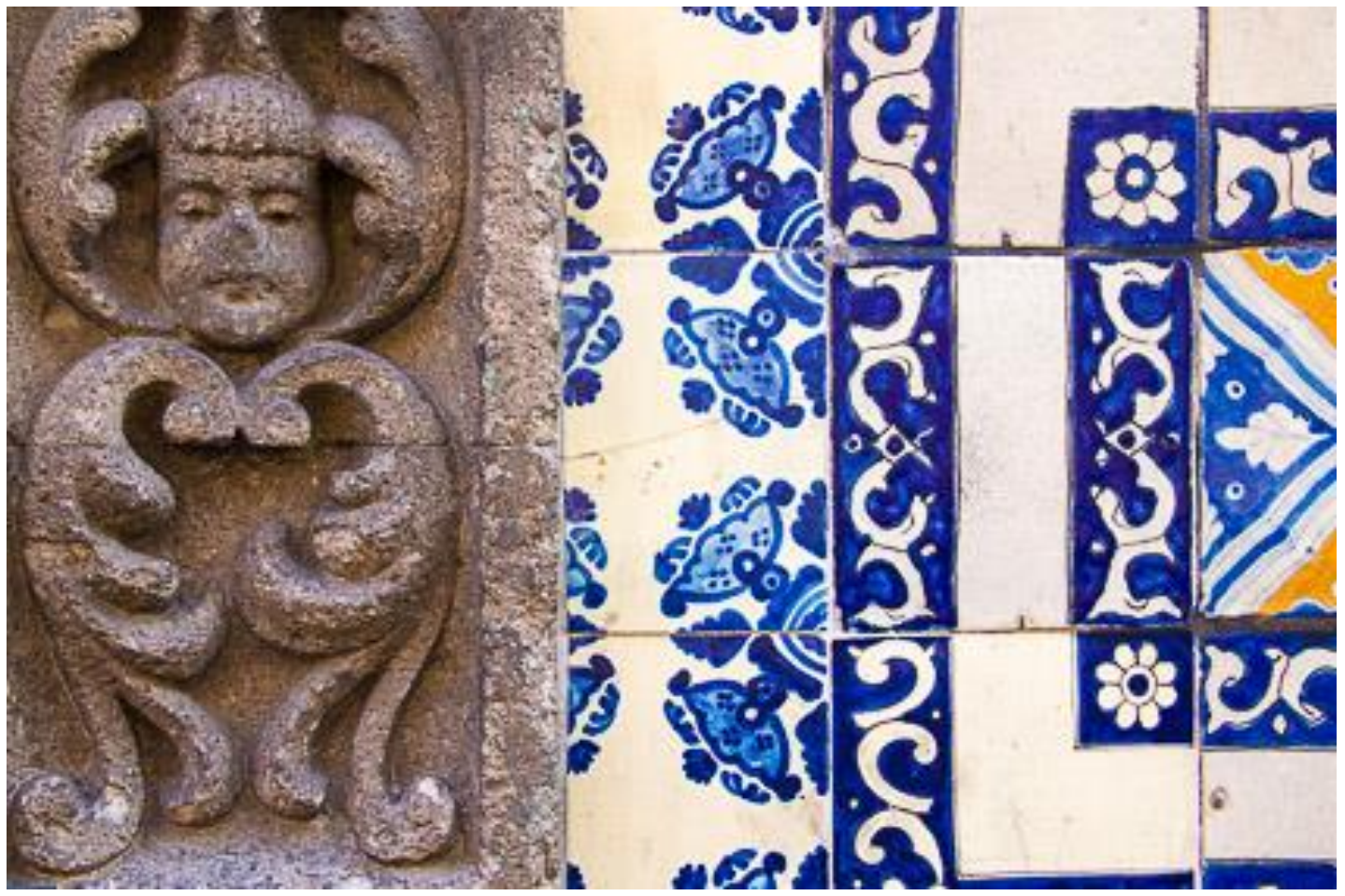


RIF, Ponta Grossa/ PR Volume 18, Número 41, p.249-263, Julho/Dezembro 2020

Foto 11: Museu Soumaya, iluminado pelo "rosa mexicano"

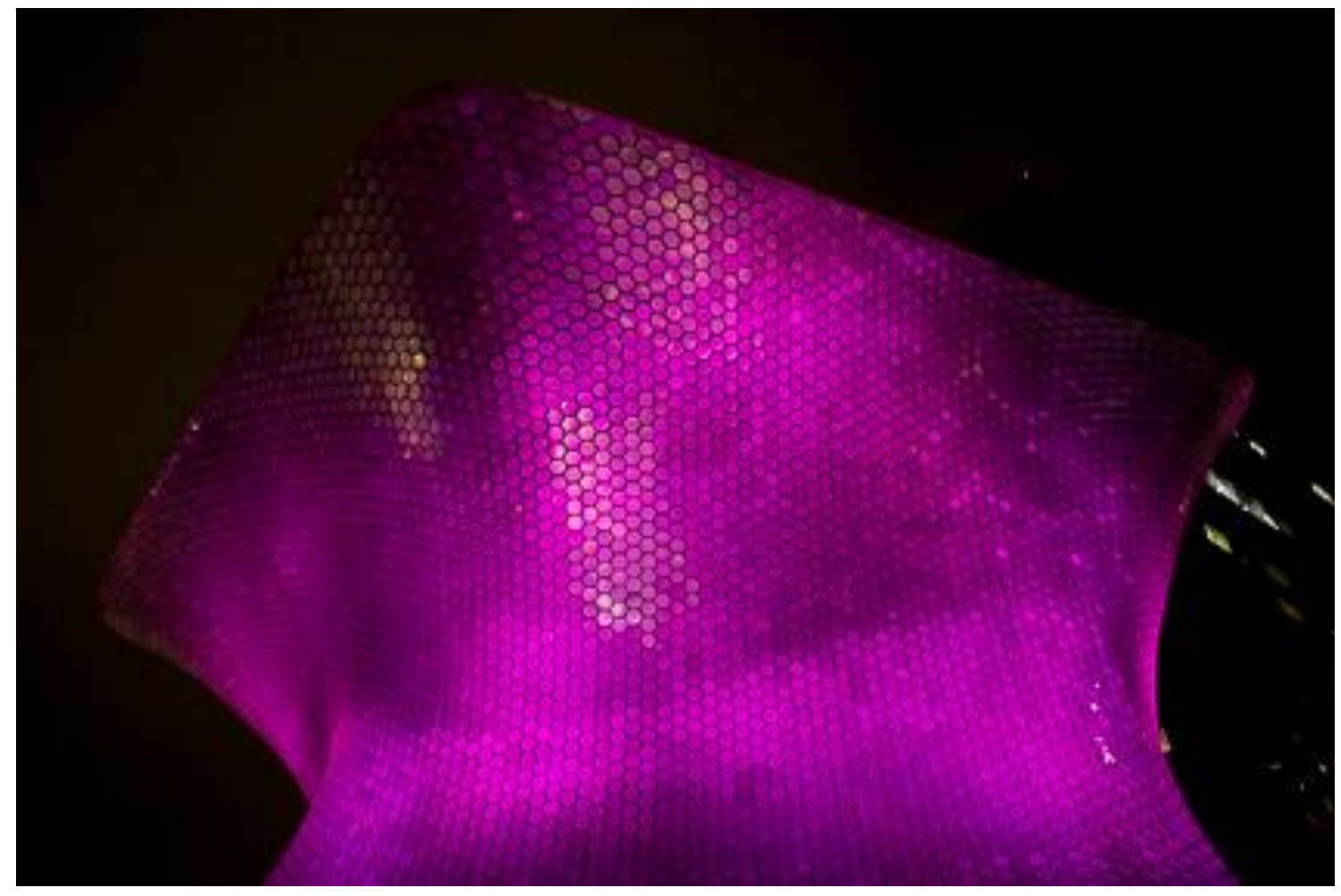

Foto 12: As gôndolas de Xochimilco

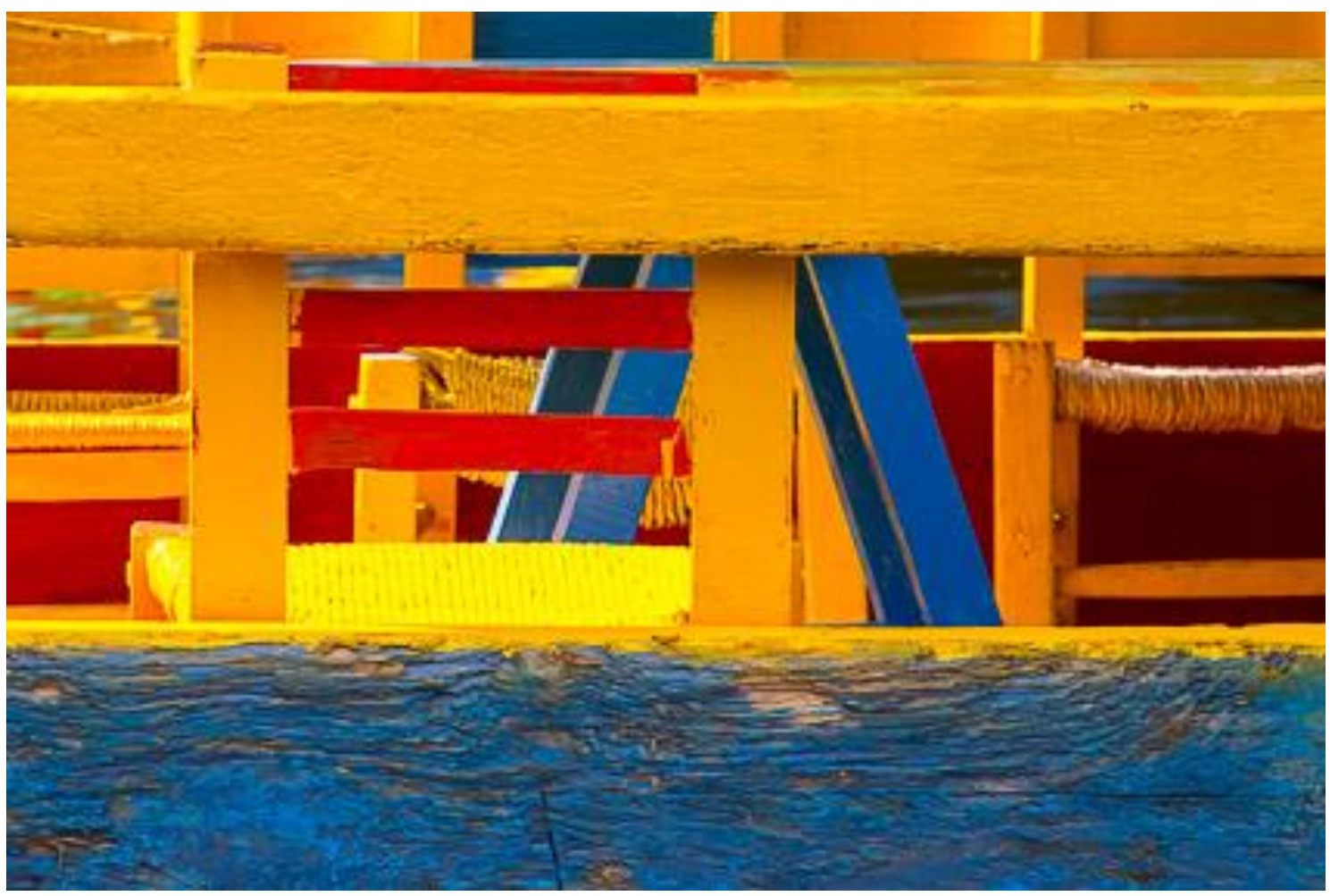


RIF, Ponta Grossa/ PR Volume 18, Número 41, p.249-263, Julho/Dezembro 2020

Foto 13: $O$ ateliê de Frida Kahlo, suas tintas, seus pincéis, suas cores

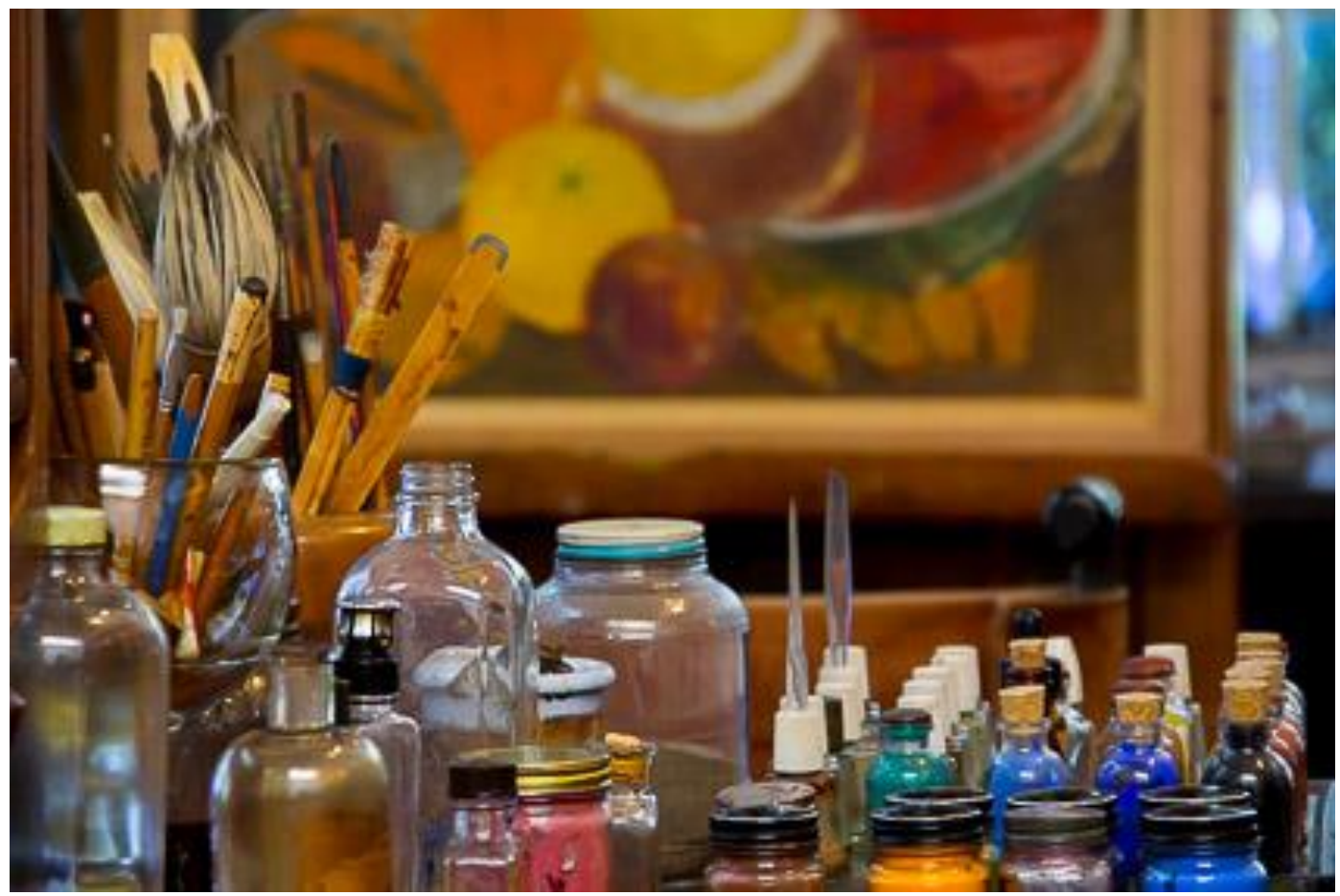

Foto 14: A quinceañera e seus chambelanes, uma expressão da alma festiva mexicana.

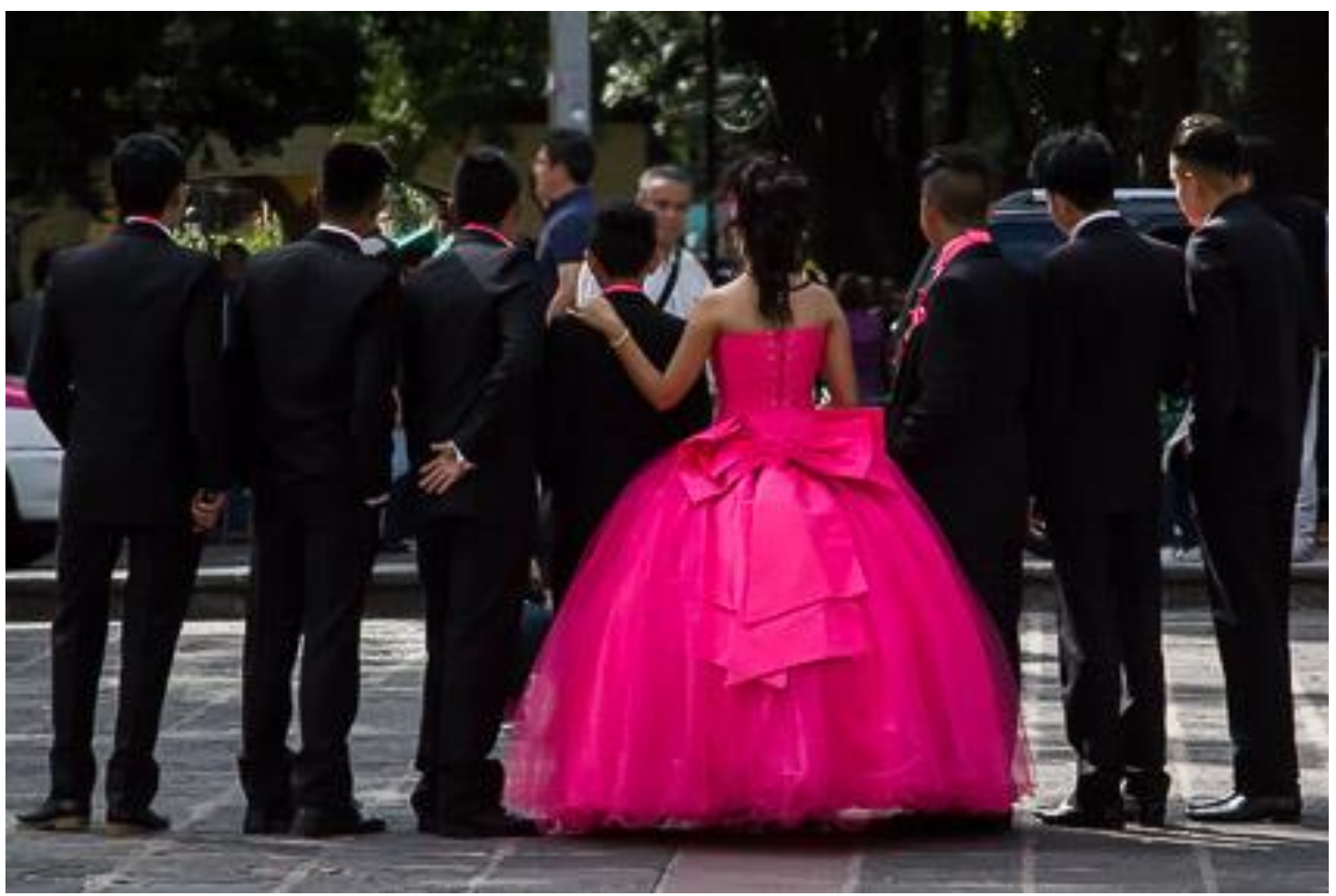




\section{RIF, Ponta Grossa/ PR Volume 18, Número 41, p.249-263, Julho/Dezembro 2020}

Foto: 15: Fonte iluminada no Monumento à Revolução, espetáculo de luz e movimento.

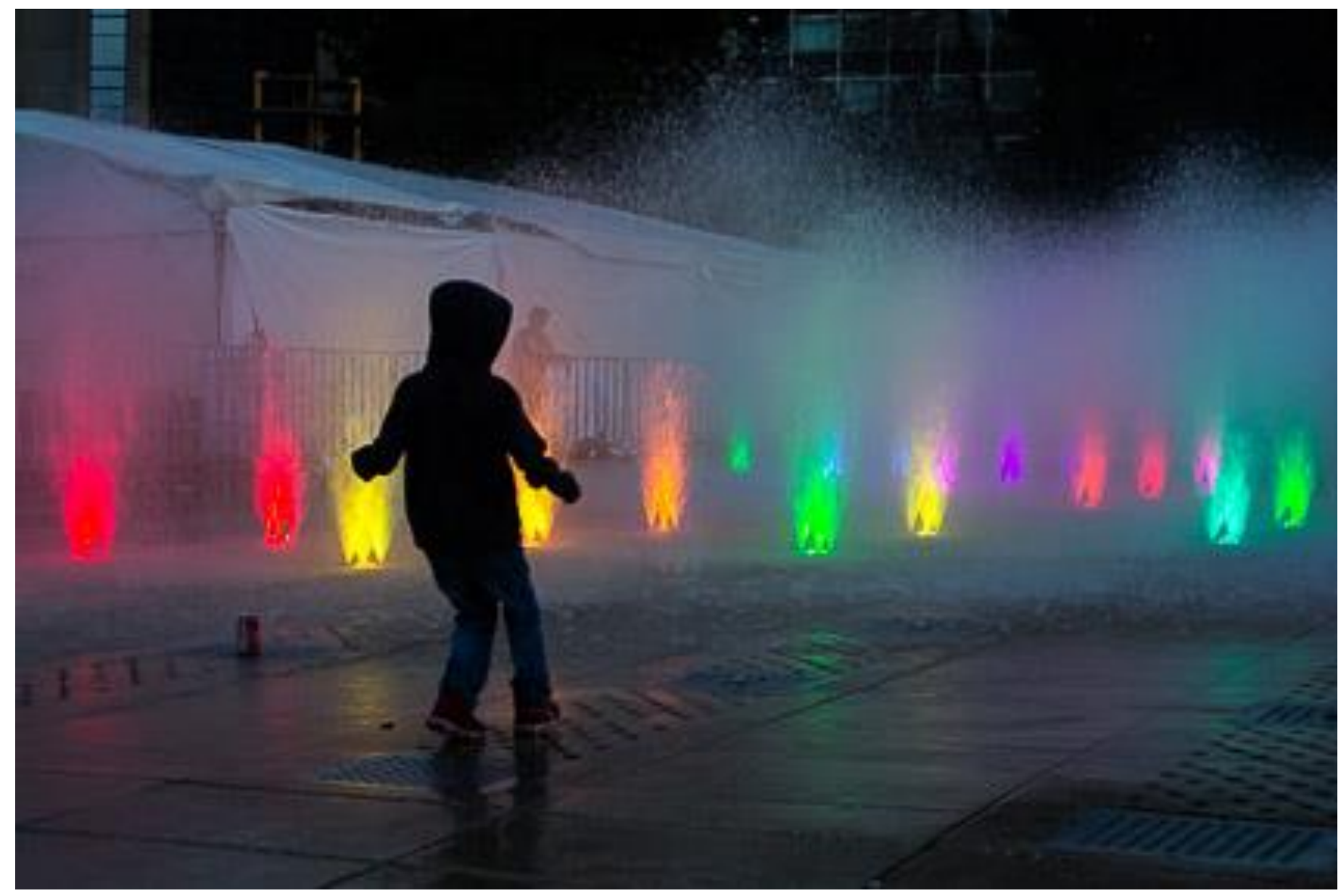

\section{Referências}

ARIZPE, Lourdes. Cultura e identidad: mexican os en la era global. Revista de la Universidad de México [online], n. 92, p. 70-81, oct. 2011. Disponível em:

<http://www.revistadelauniversidad.unam.mx/9211/pdf/92arizpe.pdf>. Acesso em 12 mar. 2019.

BORTOLI, Mario De; MAROTO, Jesús. Colours across cultures:translating colours in interactive marketing communications. Global Propaganda [online], 2008. Disponível em:

<https://globalpropaganda.com/articles/TranslatingColours.pdf>. Acesso em 12 mar. 2019.

HOOPLEY, Jenny. Cultural color differences: Mexico \& USA. Colour Lovers [online], 28 nov. 2010. Disponível em: <http://www.colourlovers.com/blog/2010/11/28/cultural-colordifferences-mexico-usa>. Acesso em 12 set. 2019.

LUCENA, Paola Lili. Erico Veríssimo e Vianna Moog: olhares sobre o México, sua história e sua cultura. In: Anais do II Simpósio Internacional Pensar e Repensar a América Latina, São 


\section{RIF, Ponta Grossa/ PR Volume 18, Número 41, p.249-263, Julho/Dezembro 2020}

Paulo,17-21 out. 2016. Disponível em: <https://sites.usp.br/prolam/wpcontent/uploads/sites/35/2016/12/LUCENA_SP11-Anais-do-II-Simpósio-Internacional-Pensare-Repensar-a-América-Latina.pdf>. Acesso em 12 mar. 2019.

MUKHOPADHYAY, Tirtha et al. Rosa mexicano: the social optics of a colour neologism. International Colour Association Internationale [online], n. 20. p. 12-27, 2017. Disponível em: https://www.researchgate.net/publication/321369926_Rosa_mexicano_the_social_optics_of _a_colour_neologism>. Acesso em 12 mar. 2019.

TEIXEIRA, Lauro Henrique de Paiva Signos naturais e culturais: o significado das cores no tempo e no espaço. Estudos Lingüísticos [online], n. XXXV, p. 1097-1106, 2006. Disponível em: <http://www.gel.org.br/estudoslinguisticos/edicoesanteriores/4publica-estudos2006/sistema06/583.pdf>. Acesso em 12 mar. 2019.

VERISSIMO, Erico. México: a história de uma viagem. 9 ed .Rio de Janeiro: Editora Globo, 1978. 